At-Tijaroh : Jurnal Ilmu Manajemen dan Bisnis Islam

Volume 6 Nomor 2 Ed.Juli-Desember 2020 : Hal 261 - 274

p-ISSN : 2356-492x

e-ISSN : 2549-9270

\title{
DETERMINAN PREFERENSI MASYARAKAT MUSLIM DALAM MEMILIH HOTEL SYARIAH
}

\author{
Muhammad Yafiz', Yenni Samri J Nasution², Khairur Rijal3 \\ Universitas Islam Negeri Sumatera Utara \\ Jl. William Iskandar Ps. V, Medan Estate, Kab. Deli Serdang, Sumatera Utara \\ 1muhammadyafiz@yahoo.co.id \\ ²yenni.samri@uinsu.ac.id \\ 3rijalmkhairur@gmail.com
}

\begin{abstract}
This research tries to analyze the factors that determine the preferences of Medan's Muslim community towards the selection of sharia hotels. The method used in this research is quantitative by taking a sample of 100 people from the Muslim City community who stay at the Sharia Hotel chosen by the researcher. The method of data analysis uses multiple linear regression with the help of SPSS Version 21.o. From the results of research conducted showed that the partial variables are also simultaneous price, halal, facilities, interests and motivation towards the preferences of the Medan City Muslim community in the selection of sharia hotels. From these variables, the overnight stay of finance from the sharia hotel sector in Medan increased.
\end{abstract}

Keywords: Sharia Hotels, Muslim Community Preferences, Prices, Facilities, Halal, Interest, Motivation

\begin{abstract}
Abstrak
Penelitian ini bertujuan untuk menganalisis faktor-faktor yang menentukan preferensi masyarakat muslim Kota Medan terhadap pemilihan hotel syariah. Penelitian ini menggunakan pendekatan kuantitatif dengan sampel yang diambil sebanyak 100 Orang dari masyarakat Muslim Kota Medan yang menginap di Hotel Syariah. Metode analisis data menggunakan regresi linier berganda dengan bantuan program SPSS Versi 21.0. Dari hasil penelitian yang dilakukan menunjukkan bahwa secara parsial maupun simultan variabel harga, kehalalan, fasilitas, minat dan motivasi berpengaruh terhadap preferensi masyarakat Muslim Kota Medan dalam pemilihan hotel syariah. Dari kelima variabel tersebut yang memiliki pengaruh paling paling besar adalah variabel kehalalan dengan Koefiseien Beta 0,442, oleh karena itu kepada seluruh stakeholder terkait agar lebih aktif dalam memperkenalkan kelebihan-kelebihan hotel syariah guna meningkakatkan kepercayaan masyarakat terhadap hotel syariah agar masyarakat lebih memilih hotel syariah sebagai pilihan menginap sehingga perekonomian dari sektor hotel syariah di kota Medan meningkat.
\end{abstract}

Kata Kunci: Hotel Syariah, Preferensi Masyarakat Muslim, Harga, Fasilitas, Kehalalan, Minat, Motivasi 
262 Determinan Preferensi Masyarakat Muslim Dalam Memilih Hotel Syariah

\section{PENDAHULUAN}

Indonesia dengan penduduk muslim terbesar didunia seharusnya dapat menjadi negara dengan ekonomi yang kuat, namun hal ini belum sejalan dengan kenyataan yang ada, Indonesia saat ini dianggap sebagai negara yang paling konsumtif dalam penggunaan produk luar negeri, ditambah lagi mainset sebagian orang yang memiliki keuangan lebih menganggap penggunaan barang import lebih baik dari pada produk dalam negeri sendiri. Begitu juga halnya dalam penggunaan jasa khususnya pariwisata. Atmosfir di dunia pariwisata memberikan keuntungan ekonomis yang cukup tinggi, sehingga mampu membawa pengaruh pada pendapatan negara dan kesejahteraan masyarakat. Kunjungan wisatawan dapat mendukung pendapatan bagi masyarakat sekitar, sehingga mampu memberikan keuntungan bagi pemilik usaha dan juga membuka peluang kerja bagi masyarakat di luar sektor pariwisata(Sabri, 2010). Perkembangan wisata di Indonesia setiap tahun mengalami perkembangan, banyaknya wisatawan yang berkunjung harus diimbangi dengan pembenahan tempat wisata, mulai dari lokasi wisata itu sendiri, fasilitas dan makanan yang ada, hingga kenyamanan tempat, serta hiasan-hiasan dan taman-taman, dan yang tidak terlepas adalah tempat penginapan yang selalu dalam pembenahan, Kontribusi dari sektor wisata Indonesia terhadap income bagi negara sudah mengalami peningkatan mulai 10\% hingga 17\% dari akumulasi ekspor barang dan jasa, meningkat menjadi penyumbang devisa terbesar ke 4, dari penyumbang devisa tersebesar ke 5 , dengan penghasilan devisa sebanyak 10 miliar USD. Penyerapan tenaga pekerja pada sektor ini sudah mencapai 10,18 juta orang atau $8,9 \%$ dari total jumlah pekerja. Jadi pariwisata merupakan salah satu pencipta tenaga kerja terbesar ke empat di Indonesia(Pradesyah \& Khairunnisa, 2018). Hal ini menjadi gambaran peningkatan tumbuhnya industi hotel syariah yang ada di Indonesia. Terkait dengan perkembangan wisata, perkembangan wisata halal Indonesia cukup pesat dalam beberapa tahun terakhir. Hal ini berimbas pada sejumlah akomodasi penunjang, salah satunya hotel syariah. Berdasarkan SK Menteri Pariwisata, Pos, dan Telekomunikasi No. KM 37/ PW. 340/ MPPT-86, hotel merupakan suatu jenis akomodasi yang mempergunakan sebagian atau seluruh bangunan untuk menyediakan jasa penginapan, makanan dan minuman, serta jasa penunjang lainnya bagi umum yang dikelola secara komersial. Hotel syariah mempunyai standar tersendiri dalam mempasilitasi minuman dan makanan yang dijamin kehalalannya. Sesuai dengan standar penyediaan makanannya, proses pembuatannya, hingga cara menghidangkan makanan. Adapun daftar nama hotel syariah dikota Medan terdiri dari Hotel Syariah Grand Jamee, Airy Eco Syariah Medan Sunggal Kantil, Madani Hotel Medan, Hotel Syariah Al Jayri, Hanlis Hotel Syariah, Hotel Syariah Aceh House, Grand Darussalam Hotel, Oyo 1286 Hotel Islami Aceh House, Hotel 
Kanasha, Ayahanda Residence Syariah. Pada daftar nama hotel tersebut, peneliti memilih 10 hotel disini berdasarkan kategori syariah ditetapkan oleh MUI yaitu kategori hilal 1 dan juga hilal 2. Pada dasarnya, hotel syariah merupakan hotel yang memberikan pelayanan dan penyajiannya berdasarkan ajaran yang sesuai dengan syariah. Namun, salah satu untuk memperoleh atau menyediakan hitel berkategori syariah, menejemen hotel harus mendapatkan dan memiliki sertifikasi halal dari Majelis Ulama Indonesia (MUI), yangmana salah satu syaratnya yaitu pihak hotel dilarang untuk menyediakan makanan dan minuman yang mengandung alkohol. Dalam hal ini pembagian kriteria hotel syariah yang ditetapkan MUI terbagi 2 yaitu hotel syariah dengan kategori hilal 1 dan hilal 2. Dalam penjelasan diatas hotel syariah sendiri yang diteliti peneliti jika dilihat dari penerapan syariahnya , 10 hotel yang tertera diatas belum mendapatkan sertifikat syariah.

Beberapa penjelasan mengemukakan, bahwa hilal 1 merupakan hotel syariah yang masih memiliki kelonggaran terhadap aturan syariah. Misalnya, dalam hotel syariah Hilal 1 ini setiap makanan dan restoran dipastikan halal. Artinya, restoran atau dapur sudah ada sertifikasi halal dari MUI. Segala peralatan yang ada sama sekali tidak ada unsur tidak halal. Tidak ada daging hewan yang dilarang di sini. Namun untuk minuman masih diperbolehkan menyediakan wine atau alkohol. Pada prinsipnya penjelasan teori mengenai hotel syariah yang dilampirkan sebagai pendukung rujukan ciri hotel yang berhak mendapat sertifikasi syariah bukan hanya sekedar menggunakan nama syariah setelah nama hotelnya, namun kesesuaian penerapan hotel syariah dengan prinsip syariah itu sendiri, hal ini sudah banyak terdapat pada hotel syariah di Medan hanya saja hotel syariah di Medan belum memiliki sertifikat hotel syariah. Pada Hotel Hilal 1, kriterianya di hotel tersebut harus memiliki kemudahan dalam bersuci dan beribadah, jadi pihak totel harus menyediakan toilet shower bukan hanya tissue, makanan halal, tapi tidak ada seleksi tamu, dapurnya sudah bersertifikat halal, namun hanya dapurnya saja, akan tetapi minuman seperti wine masih boleh ada karena bukan najis aini, namun halan apabila diminum. Intinya bahwa kalau makan masih bisa dijamin kehalalannya.

Sementara untuk Hilal 2, dijelaskan segala sesuatu hal yang tidak diperbolehkan dalam aturan syariah memang sudah diterapkan dalam hotel syariah ini. Hilal 2 memang semua fasilitas harus dengan syariah, Chanel MTV di tiadakan dalam TV, semua fasilitas tidak ada alcohol, tamu diseleksi. Hotel Hilal 2 ini secara operasional sudah memenuhi ketentuan syariah. Dalam hal ini Indonesia yang mayoritas muslim melakukan pengembangan hotel syariah dengan nilai kultural budaya Islam nusantara yang beragam dalam upaya peningkatan kehidupan yang lebih baik lagi. Jika dilihat pada jumlah penduduk kota Medan adalah mayoritas beragama Islam dengan jumlah 1.601.296 jiwa dari total 2.434.320 Jiwa di Kota Medan. Jumlah penduduk muslim yang besar di 
264 Determinan Preferensi Masyarakat Muslim Dalam Memilih Hotel Syariah

Kota Medan seharusnya mengindikasikan hotel syariah sangat diminati dan juga dapat lebih dikembangkan. Dengan populasi yang mendominasi umat muslim maka sampel yang akan ditelitipun akan lebih mudah untuk dilihat berdasarkan kriteria umur pekerjaan dan keperluan dalam menginap di hotel syariah itu sendiri.

Ada beberapa preferensi masyarakat dalam memilih sesuatu, salah satunya adalah preferensi konsumen. Preferensi konsumen menunjukkan kesukaan konsumen dari berbagai pilihan produk atau jasa yang ada. Teori preferensi dapat digunakan untuk menganalisis tingkat kepuasan bagi konsumen, misalnya bila seseorang ingin mengkonsumsi atau menggunakan sebuah produk atau jasa dengan sumber daya terbatas maka ia harus memilih alternatif pilihan sehingga nilai guna atau utilitas yang diperoleh mencapai optimal. Sementara berdasarkan Andi Mappiare definisi preferensi adalah suatu perangkat mental yang terdiri dari suatu campuran dari perasaan, harapan, pendirian, prasangka, rasa takut atau kecenderungan lain yang mengarahkan individu kepada suatu piliha tertentu(Mappiare, 1994).

Preferensi konsumen dapat diketahui dengan mengukur tingkat kegunaan dan nilai relatif penting setiap atribut yang terdapat pada suatu produk atau jasa. Daya tarik pertama yang dapat menimbulkan dan mempengaruhi konsumen yaitu berupa atribut yang dimunculkan pada suatu produk atau jasa. Penilaian terhadap jasa dan produk menggambarkan sikap konsumen terhadap produk atau jasa tersebut, sekaligus dapat mencerminkan perilaku konsumen dalam menggunakan atau mengkonsumsi suatu produk atau jasa. Berdasarkan uraian teori yang dijelaskan maka faktor-faktor yang dianggap mempengaruhi preferensi masyarakat Kota Medan terhadap hotel syariah meliputi beberapa variabel independen yaitu harga, fasilitas, kehalalan, minat dan motivasi. Ini dilihat dari pemilihan variabel yang diteliti disesuaikan dengan kondisi lapangan dan juag referensi baik penelitian terdahulu serta juga penelitian dasar seperti wawancara terhadap tamu dan juga pegawai hotel syariah itu sendiri sehingga ini dinilai relevan untuk diteliti.

Ada beberapa faktor yang dapat memengaruhi preferensi konsumen dalam memilih hotel syariah, yaitu harga, fasilitas, kehalalan, minat dan motivasi. Menurut (Kotler \& Keller, 2009) pada dasarnya harga adalah salah satu elemen bauran pemasaran atau marketing mix yang dapat menghasilkan pendapatan, dimana elemen yang lain mendapatkan biaya, dan satu-satunya unsur bauran pemasaran yang seringkali dijadikan sebagai bahan pertimbangan bagi konsumen yaitu 'Harga' yang merupakan suatu kegiatan dalam melakukan pembelian yang tidak bisa dikesampingkan oleh perusahaan. Basu Swastha menyatakan bahwa harga sebagai sejumlah uang (ditambah beberapa produk) yang dibutuhkan untuk mendapatkan sejumlah kombinasi dari produk dan pelayanannya(Swastha, 2001). Berdasarkan penjelasan diatas dapat dipahami 
bahwa harga yang diberikan atau dibayar oleh pembeli sudah termasuk layanan yang diberikan oleh penjual. Banyak perusahaan-perusahaan telah membuat pendekatan-pendekatan terhadap penentuan harga yaitu berdasarkan tujuan yang hendak dicapainya. Adapun tujuan tersebut dapat berupa mempertahankan stabilitas harga, meningkatkan mutu penjualan, meningkatkan dan mempertahankan market share, serta mencapai laba maksimum dan sebagainya.

Para penyedia jasa selalu sengaja untuk memberikan tingkat kepuasan yang masksimal kepada konsumennya melalui peningkatan fasilitas layanan pada market sharenya dengan bertujuan memberikan tingkat kepuasan yang maksimal. Fasilitas merupakan segala sesutau yang bersifat peralatan fisik yang disediakan oleh pihak penjual jasa untuk mendukung kenyamanan konsumen(Kotler, 2009). Sedangkan Menurut Lupioadi, fasilitas merupakan penampilan, kemampuan sarana prasarana dan keadaan lingkungan sekitarnya dalam menunjukkan eksistensinya kepada eksternal yang meliputi fasilitas fisik (gedung) perlengkapan dan peralatan(Lupyoadi dkk., 2008). Tjiptono mengatakan bahwa desain dan tata letak fasilitas jasa erat kaitannya dengan pembentukan presepsi pelanggan(Tjipto, 2008).

Factor berikutnya adalah kehalalan, kehalalan adalah segala objek atau kegiatan yang diizinkan untuk digunakan atau dilaksanakan, dalam agama Islam. Kata halal adalah istilah bahasa Arab dalam agama Islam yang berarti 'diizinkan' atau 'boleh'. Secara etimologi, halal berarti hal-hal yang boleh dan dapat dilakukan karena bebas atau tidak terikat dengan ketentuanketentuan yang melarangnya(Qardhawi, 2007). Masyarakat muslim telah diajarkan untuk mengkonsumsi produk-produk yang yang baik serta halal. Islam telah mengajarkan ada tiga kluster produk untuk masyarakat muslim yaitu halal, haram, dan mushbooh. Halal dalam bahasa arab berarti diizinkan, bisa digunakan, dan sah menurut hukum. Sementara kebalikan dari halal yaitu haram yang berarti tidak diizinkan, tidak bisa digunakan, dan tidak sah menurut hukum, sedangkan mushbooh (syubha, shubhah, dan mashbuh) berarti hitam putih, masih dipertanyakan, dan meragukan oleh karena itu sebaiknya dihindari.

Selain kehalalan, factor minat juga dapat memengaruhinya, Andi menjelaskan bahwa minat merupakan suatu ketertarikan individu terhadap satu obyek tertentu yang membuat individu itu sendiri merasa senang dengan obyek tersebut. Minat merupakan suatu perangkat mental yang terdiri dari campuran-campuran harapan, perasaan, pendidikan, rasa takut atau kecenderungan-kecenderungan lain yang menggerakan individu kepada suatu pilihan tertentu(Mappiare, 1994).

Bisnis Hotel Syariah saat ini sudah ada beberapa di Medan dan akan terus meningkat jumlahnya hal ini menggambarkan bahwasanya masyarakat menyukai Hotel Syariah untuk 
menginap dan menimbulkan pertanyaan di benak kita apa sebenarnya yang menentukan masyarakat Muslim dalam memilih hotel syariah dilandasi dengan semangat ekonomi islam serta dibarengi beberapa faktor yang berupa Harga, Fasilitas, Kehalalan, Minat, dan Motivasi pada Masyarakat Kota Medan, sehingga peneliti tertarik untuk melakukan penelitian ini.

\section{METODE PENELITIAN}

Jenis penelitian yang digunakan terhadap penelitian ini adalah penelitian kuantitatif. Dengan Objek Penelitian sendiri adalah masyarakat muslim sekitar Kota Medan yang meliputi para pengguna hotel syariah itu sendiri serta para stake holder terkait. Pemilihan lokasi penelitian terkait keberadaan Kota Medan Sebagai ibu Kota provinsi yang ada disumatera utara, sehingga pengembangan hotel syariah itu sendiri lebih banyak diKota Medan. Dengan Populasi meliputi seluruh karakteristik yang di miliki subyek atau objek itu(Azwar, 2012).

Dalam hal ini populasi yang peneliti teliti adalah masyarakat Kota Medan Pengguna Hotel Syariah yang berada di beberapa hotel yang telah dipilih peneliti berjumlah 13744 orang. Sedangkan salah satu metode yang digunakan untuk menentukan sampel adalah menggunakan rumus Slovin. Penetuan sampel terhadap penelitian ini menggunakan rumus teori solvin yaitu $n=\frac{N}{N \cdot d^{2}+1}$ dimana $n$ adalah ukuran sampel, $N$ adalah ukuran populasi dan $d$ adalah galat pendugaan (10 \%). Maka perhitungan sampel adalah sebagai berikut.

$$
n=\frac{13.744}{(13.744)(10 \%)^{2}+1}=\frac{312}{138,44}=99,277 \approx 100
$$

Berdasarkan penentuan sampel tersebut, maka dari jumlah populasi di atas adalah 13.744 orang, maka jumlah sample yang akan diteliti sebanyak 100 responden. Kemudian data yang diperoleh akan dianalisis dengan regresi analisis berganda melalui bantuan spss, dengan rumus.

$$
Y=\alpha+b_{1} \cdot x_{1}+b_{2} \cdot x_{2}+b_{3} \cdot x_{3}+b_{4} \cdot x_{4}+b_{5} \cdot x_{5}
$$

dimana:

Y : Preferensi Masyarakat,

a : Konstanta

$b_{1} b_{2} \ldots$ : Koefisien korelasi ganda,

$x 1$ : Harga,

X2 : Fasilitas,

$x 3$ : Kehalalan,

$x 4$ : Minat, 
$x 5 \quad$ : Motivasi

Berdasarkan model penelitian diatas, maka diajukan hipotesis sebagai jawaban sementara dari penelitian ini sebagai berikut.

$\mathrm{H}_{1}=$ Terdapat pengaruh positif Harga terhadap Preferensi Masyarakat Muslim dalam memilih Hotel Syariah

$\mathrm{H}_{2}=$ Terdapat pengaruh positif Fasilitas terhadap Preferensi Masyarakat Muslim dalam memilih Hotel Syariah

$\mathrm{H}_{3}=$ Terdapat pengaruh Kehalalan terhadap Preferensi Masyarakat Muslim dalam memilih Hotel Syariah

$\mathrm{H}_{4}=$ Terdapat pengaruh Minat terhadap Preferensi Masyarakat Muslim dalam memilih Hotel Syariah

$\mathrm{H}_{5}=$ Terdapat pengaruh Motivasi terhadap Preferensi Masyarakat Muslim dalam memilih Hotel Syariah

$\mathrm{H}_{6}=$ Secara Bersama-Sama Terdapat pengaruh positif antara Harga, Fasilitas, Kehalalan, Minat dan Motivasi terhadap Preferensi Masyarakat Muslim dalam memilih Hotel Syariah

\section{HASIL DAN PEMBAHASAN}

Hasil dari uji validitas dari angket yang disebarkan pada responden yang kemudian diolah dengan SPSS. Semua pernyataan valid. Terbukti dari nilai $r_{\text {hitung }}$ yang lebih besar dari $r_{\text {tabel }}\left(r_{\text {hitung }}\right.$ $\left.>r_{\text {tabel}}\right)$. Berarti, seluruh item pernyataan dalam angket yang digunakan dalam penelitian ini tepat digunakan untuk mengukur variabel dalam penelitian ini. Hasil uji validitas dapat dilihat pada tabel berikut.

\section{Tabel 1}

\section{Uji Validitas Variabel-Variabel Penelitian}

\begin{tabular}{ccccc}
\hline Variabel & Pernyataan & R hitung & R tabel & Keterangan \\
\hline Harga & Pertanyaan 1 & 0,453 & & Valid \\
& Pertanyaan 2 & 0,455 & \multirow{2}{0}{ Valid } \\
& Pertanyaan 3 & 0,391 & Valid \\
& Pertanyaan 4 & 0,342 & & Valid \\
& Pertanyaan 5 & 0,484 & & \\
& & & & Valid \\
Fasilitas & Pertanyaan 1 & 0,408 & \multirow{2}{0}{ V,205 } & Valid \\
& Pertanyaan 2 & 0,286 & & Valid \\
& Pertanyaan 3 & 0,353 & & \\
& Pertanyaan 4 & 0,328 & & Valid
\end{tabular}


268 Determinan Preferensi Masyarakat Muslim Dalam Memilih Hotel Syariah

$\begin{array}{lll}\text { Pertanyaan 2 } & 0,346 & \text { Valid } \\ \text { Pertanyaan 3 } & 0,459 & \text { Valid } \\ \text { Pertanyaan 4 } & 0,256 & \text { Valid } \\ \text { Pertanyaan 5 } & 0,428 & \end{array}$

Minat

Pertanyaan 1

0,456

Valid

Pertanyaan 2

0,331

Pertanyaan 3

0,473

Pertanyaan 4

0,378

Valid

Pertanyaan 5

o,396

Motivasi

Pertanyaan 1

0,436

0,328

Pertanyaan 2

0,443

Pertanyaan 3

0,246

Pertanyaan 4

0,431

Preferensi

Pertanyaan 1

0,547

0,561

Pertanyaan 2

0,588

0,360

Pertanyaan 4

0,467

Berdasarkan nilai $\mathrm{r}_{\text {tabel }}$ untuk uji dua sisi pada taraf jarak 95\% atau signifikansi $5 \%(\mathrm{p}=$ 0,05) dapat dicari berdasarkan jumlah responden atau $\mathrm{N}$. Oleh karena $\mathrm{N}=100$, maka derajat bebasnya (df) adalah $\mathrm{N}-2(100-2=98)$. Pada buku-buku statistik, nilai $r$ tabel satu sisi pada $\mathrm{df}=98$ dan $\mathrm{p}=0,05$ adalah 0.205 . Butir pertanyaan dinyatakan valid jika jika nilai $\mathrm{r}_{\text {hitung }}>\mathrm{r}_{\text {tabel. }}$. Maka kesimpulannya bahwa semua butir pertanyaan pada semua variabel yang diteliti adalah valid.

Tabel 2

Hasil Uji Reliabilitas Penelitian

\begin{tabular}{lcc}
\hline \multicolumn{1}{c}{ Variabel } & Nilai Cronbach Alpha & Keterangan \\
\hline Harga & 0,624 & Reliabel \\
Fasilitas & 0,587 & Cukup Reliabel \\
Kehalalan & 0,598 & Cukup Reliabel \\
Minat & 0,624 & Reliabel \\
Motivasi & 0,590 & Cukup Reliabel \\
Preferensi Masyarakat & 0,728 & Reliabel \\
\hline
\end{tabular}


Hasil penelitian menunjukan bahwa nilai cronbach's alfa memiliki nilai > dari o,5870,727 menunjukkan bahwa Cornbach alpha dari semua variabel yang diteliti masing-masing bernilai cukup reliable dan reliabel dan dapat digunakan dalam penelitian.

\section{Tabel 3}

Uji Normalitas Variabel Penelitian

\begin{tabular}{cccc}
\hline Keterangan & Asymp. Sig. (2-tailed) & Sig. & Keputusan \\
\hline Unstandardized Residual & 0,762 & 0,10 & Normal \\
\hline
\end{tabular}

Hasil dari data tabel diatas, dapat dilihat bahwa nilai Kolmogorov-Smirnov (K-S) yang diperoleh Y adalah o,669 dan tingkat signifikansi pada 0,762 yang lebih besar dari tingkat signifikansi 0,05. Dengan demikian dapat disimpulkan bahwa data dalam model regresi telah terdistribusi secara normal.

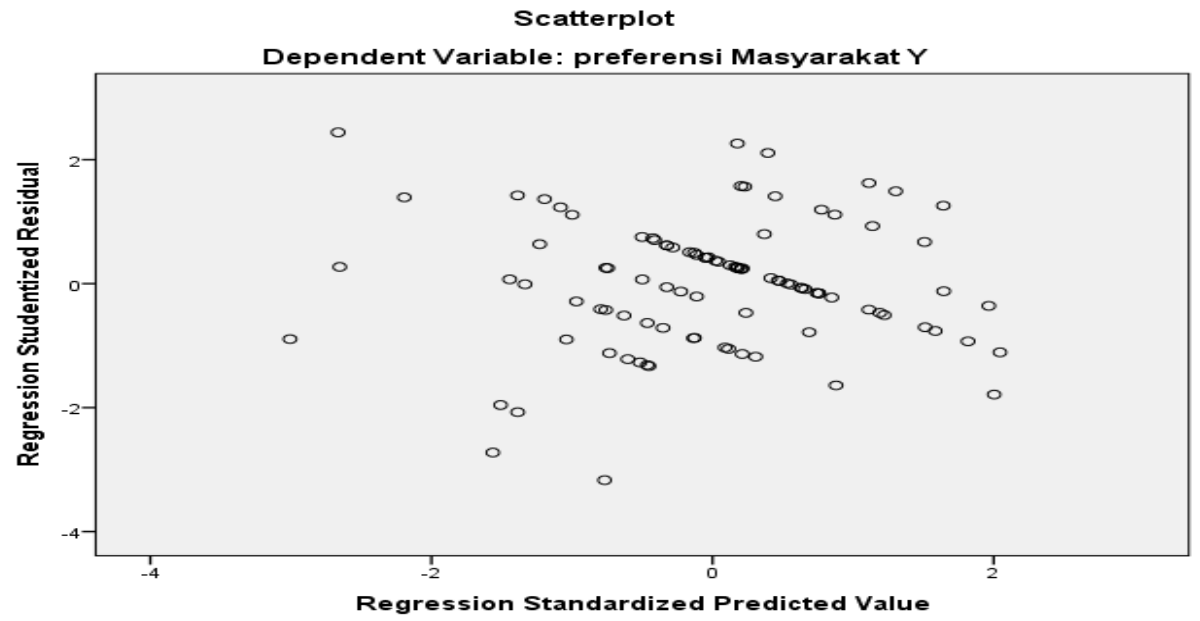

Gambar 1. Hasil Uji Heteroskedastisitas

Berdasarkan dari gambar di atas bahwa data tidak mempunyai gangguan heteroskedastisitas karena tidak ada pola tertentu pada grafik yang relatif menyebar baik di atas sumbu nol maupun di bawah sumbu nol.

\section{Tabel 4}

\section{Uji Multikolinearitas}


270|Determinan Preferensi Masyarakat Muslim Dalam Memilih Hotel Syariah

\begin{tabular}{cccc}
\hline Variabel & VIF & Ketentuan & Keputusan \\
\hline Harga & 1,507 & $<10$ & Bebas Multikolinearitas \\
Fasilitas & 1,370 & $<10$ & Bebas Multikolinearitas \\
Kehalalan & 1,505 & $<10$ & Bebas Multikolinearitas \\
Minat & 1,352 & $<10$ & Bebas Multikolinearitas \\
Motivasi & 1,604 & $<10$ & Bebas Multikolinearitas \\
\hline
\end{tabular}

Berdasarkan data diatas dapat diambil kesimpulan bahwa multikolinearitas terbebas terhadap penelitian ini.

Tabel 5

Uji Autokorelasi

\begin{tabular}{cccccc}
\hline Model & $\mathbf{R}$ & $\begin{array}{c}\mathbf{R} \\
\text { Square }\end{array}$ & $\begin{array}{c}\text { Adjusted R } \\
\text { Square }\end{array}$ & $\begin{array}{c}\text { Std. Error of } \\
\text { the Estimate }\end{array}$ & Durbin-Watson \\
\hline 1 &, $840^{\mathrm{a}}$ &, 705 &, 689 &, 90256 & 2,522 \\
\hline
\end{tabular}

Berdasarkan data tabel diatas diketahui bahwa nilai durbin - watson $=$ 2,522 atau diantara Angka D-W diatas +2 dengan demikian dapat disimpulkan bahwa tidak ada autokorelasi diantara variabel harga, fasilitas, kehalalann, minat, dan motivasi.

Tabel 6

Hasil Regresi Linier Berganda

\begin{tabular}{cc}
\hline Variabel & Unstandardized Coefficients \\
\hline Constanta & 3,703 \\
Harga & 0,230 \\
Fasilitas & 0,308 \\
Kehalalan & 0,442 \\
Minat & 0,368 \\
Motivasi & 0,377 \\
\hline
\end{tabular}

Dari model regresi diatas maka persamaan regresinya adalah :

$\mathrm{Y}=\mathbf{3 , 7 0 3}+\mathbf{0 , 2 3 0} \mathrm{X1}+0,308 \mathrm{X2}+0,442 X_{3}+0,368 X_{4}+0,377 \mathrm{X}_{5}+\mathrm{e}$

$\mathbf{Y}=\mathbf{a}+\mathrm{b}_{1} \mathrm{X1}_{1}+\mathrm{b}_{2} \mathrm{X}_{2}+\mathrm{b3}_{3} \mathrm{X}_{3}+\mathrm{b}_{4} \mathrm{X}_{4}+\mathrm{b}_{5} \mathrm{X}_{5}+\mathrm{e}$

Dari persamaan diatas digambarkan bahwa semua variabel X (harga, fasilitas, kehalalan ,minat, motivasi) memiliki koefisien yang positif, hal ini menggambarkan bahwa variabel bebas memiliki pengaruh yang selaras terhadap variabel Y (preferensi masyarakat). Model penelitian dalam bentuk persamaan regresi linear berganda diatas dapat diartikan sebagai berikut: 
Artinya dari hasil regresi adalah :

Nilai konstant 3,703 artinya apabila variabel (Fasilitas, Harga, Kehalalan, Minat, dan Motivasi) sama dengan nol, maka preferensi masyarakat adalah 3,703. Nilai koofesien harga o,230 artinya, jika jumlah Harga meningkat 1, maka preferensi masyarakat : 0,230. Nilai koofesien fasilitas 0,308 artinya, jika jumlah Fasilitas meningkat 1 maka preferensi masyarakat : 0,308. Nilai koofesien kehalalan o,442 artinya, jika jumlah Kehalalan meningkat 1, maka preferensi masyarakat : o,442. Nilai koofesien minat o,368 artinya, jika jumlah Minat meningkat 1, maka preferensi masyarakat : 0,368 . Nilai koofesien motivasi o,377 artinya, jika jumlah Motivasi meningkat 1, maka preferensi masyarakat : 0,377 . Dari tabel diatas diketahui bahwa nilai durbin - watson $=2,522$ atau diantara Angka D-W diatas +2 dengan demikian dapat disimpulkan bahwa tidak ada autokorelasi diantara variabel harga, fasilitas, kehalalann, minat, dan motivasi.

Tabel 7

Hasil Uji Simultan

\begin{tabular}{cccc}
\hline Uji & Sig. & Ketentuan & Keputusan \\
\hline Uji F & 0,000 & $>0,05$ & Terdapat Pengaruh \\
\hline
\end{tabular}

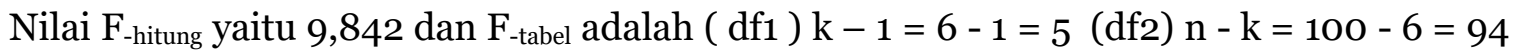
atau F-hitung > F-tabel atau 9,842 > 1,909 atau nilai p-value adalah 0,ooo pada kolom sig. < level of significant (a) 5\% maka terdapat pengaruh secara simultan antara harga, fasilitas, kehalalan, minat, dan motivasi terhadap preferensi masyarakat muslim dalam pemilihan hotel syariah di Kota Medan. Untuk mengetahui derajat keeratan pengaruh variabel harga, fasilitas, kehalalan, minat, dan motivasi terhadap preferensi masyarakat muslim terhadap pemilihan hotel syariah di Kota Medan maka dapat digunakan korelasi ganda dan dengan melihat nilai koefisien determinasi (R-Square) akan dapat diketahui bagaimana sebenarnya nilai kontribusi kedua variabel bebas terhadap terikat.

Tabel 8

Hasil Uji Koefisien Determinasi

Uji $\quad$ R Square $\quad$ Besaran Pengaruh


272 Determinan Preferensi Masyarakat Muslim Dalam Memilih Hotel Syariah
$\mathrm{R}^{2}$
0,705
70,5 Persen

Berdasarkan tabel diatas dapat dijelaskan bahwa secara bersamaan nilai koefisien korelasi ganda sebesar 0,705 bernilai positif, artinya berpengaruh variabel harga, fasilitas, kehalalan, minat, dan motivasi terhadap preferensi masyarakat muslim dalam pemilihan hotel syariah di Kota Medan sangat kuat, atau 70,5\% variabel terikat dapat dipengaruhi oleh variabel bebas, sementara 29,5\% dipengaruhi oleh variabel lain yang bukan dari variabel yang dipilih diteliti, variabel lain tersebut adalah variabel-variabel yang besaral dari faktor lain yang mempengaruhi preferensi, untuk mengetahuinya dengan cara Mengkaji lebih dalam faktor-faktor yang mempengaruhi preferensi seperti yang telah dijelaskan di landasan teori. Sebagaimana yang telah dijelaskan oleh Nugroho J Setiadi dalam buku Prilaku Konsumen faktor yang mempengaruhi preferensi terhadap barang dan jasa yaitu dipengaruhi oleh faktor kebudayaan, faktor sosial, faktor pribadi dan faktor sosiologis.

\section{Tabel 9}

Hasil Uji Parsial

\begin{tabular}{cccc}
\hline Variabel & Sig. & Ketentuan & Keputusan \\
\hline Harga & 0,041 & $<0,05$ & Terdapat Pengaruh \\
Fasilitas & 0,002 & $<0,05$ & Terdapat Pengaruh \\
Kehalalan & 0,002 & $<0,05$ & Terdapat Pengaruh \\
Minat & 0,001 & $<0,05$ & Terdapat Pengaruh \\
Motivasi & 0,000 & $<0,05$ & Terdapat Pengaruh \\
\hline
\end{tabular}

Pengaruh Harga Terhadap Preferensi Masyarakat Muslim Dalam Memilih Hotel Syariah

Harga produk berpengaruh secara signifikan terhadap preferensi konsumen. Bila harga lebih murah dan terjangkau maka preferensi konsumen membelipun akan naik(Sembiring, 2017). Harga juga dapat berpengaruh terhadap keputusan konsumen untuk memilih, siapapun konsumennya, factor pertama yang mereka akan tanyakan adalah perihal harga, karena perilaku konsumen selalu menginginkan harga yang murah(Dewi, 2016).

Pengaruh Fasilitas Terhadap Preferensi Masyarakat Muslim Dalam Memilih Hotel Syariah

Karakteristik responden menginap di hotel syariah sebanyak 1 kali, dan mengenal hotel syariah dari internet dan memprioritaskan suasana hotel syariah tersebut. Faktor yang mempengaruhi persepsi responden dalam memilih hotel syariah hanya faktor citra hotel. 
Semakin tinggi dan bagus citra hotel syariah, maka semakin tinggi atau besar orang memiilh hotel syariah melalui fasilitas-fasilitas yang diberikan oleh pihak hotel(Huda dkk., 2019).

Pengaruh Kehalalan Terhadap Preferensi Masyarakat Muslim Dalam Memilih Hotel Syariah

persepsi label halal tidak hanya dipahami oleh konsumen Muslim atau konsumen yang berlatar belakang pendidikan Islam saja, namun konsumen non-Muslimpun dan yang berlatar pendidikan berbasis umum hingga berbasis agama selain Islam memiliki persepsi positif terhadap label halal, sekalipun pemahamannya tidak sebaik konsumen Muslim. semakin besar persepsi konsumen tentang label halal maka preferensi belinya akan semakin meningkat. Produk halal memiliki kualitas yang relatif baik dan mempengaruhi baik dari segi agama, hambatan mengkonsumsi, dan sikap konsumen terhadap produk lainnya. Sehingga mental pelanggan percaya terhadap produk dengan merek halal(Dewi Samad, 2019).

\section{KESIMPULAN}

Berdasar kan hasil penelitian, hasil analisis dan pembahasan penelitian mengenai Analisis Faktor - Faktor Yang Menentukan Preferensi Masyarakat Muslim Kota Medan Terhadap Pemilihan Hotel Syariah, dapat ditarik kesimpulan, dari hasil penelitian secara parsial variabel Harga, Fasilitas, Kehalalan, Minat Dan Motivasi berpengaruh secara positif dan signifikan terhadap Preferensi Masyarakat Muslim pada Pemilihan Hotel Syariah di Kota Medan. hal ini menunjukkan bahwasanya Harga, Fasilitas, Kehalalan, Minat Dan Motivasi menjadi salah satu penentu masyarakat kota Medan dalam melakukan pemilihan Hotel Syariah.

\section{DAFTAR PUSTAKA}

Azwar, S. (2012). Metode Penelitian. Pustaka Pelajar.

Dewi, A. N. K. (2016). PENGARUH HARGA, KUALITAS, KONDISI PASAR DAN LOKASI PASAR TERHADAP PREFERENSI KONSUMEN DALAM BERBELANJA DI PASAR TRADISIONAL. E-Qien : Jurnal Ekonomi dan Bisnis, 3(2). https://stiemuttaqien.ac.id/ojs/index.php/OJS/article/view/24

Dewi Samad, T. F. (2019). Pengaruh Persepsi Label Halal Terhadap Preferensi Konsumen pada Restoran Pizza Hut dan KFC di Yogyakarta. FALAH: Jurnal Ekonomi Syariah, 4(1), 1. https://doi.org/10.22219/jes.v4i1.796o 
274 Determinan Preferensi Masyarakat Muslim Dalam Memilih Hotel Syariah

Huda, N., Zulihar, Z., \& Rini, N. (2019). FAKTOR YANG MEMPENGARUHI PREFERENSI MASYARAKAT MUSLIM MEMILIH HOTEL SYARIAH. EKUITAS (Jurnal Ekonomi dan Keuangan), 2(4), 490-511. https://doi.org/10.24034/j25485024.y2018.v2.i4.4033

Kotler, P. (2009). Manajemen Pemasaran. Prehalindo.

Kotler, P., \& Keller, K. L. (2009). Manajemen Pemasaran (13 ed.). Erlangga.

Lupyoadi, Rambat, \& Hamdani. (2008). Manajemen Pemasaran Jasa. Salemba Empat.

Mappiare, A. (1994). Psikologi Orang Dewasa Bagi Penyesuaian dan Pendidikan. Usana Offsetprinting.

Pradesyah, R., \& Khairunnisa. (2018). Analisis Penerapan Fatwa MUI Wisata Halal (Studi Kasus Hotel Syariah Medan). Jurnal INTIQAD, 1O(2), 334-348.

Qardhawi, Y. (2007). Halal dan Haram Dalam Islam. Era Intermedia.

Sabri, F. A. (2010). Perkembangan Hotel Syari'ah di Indonesia; Mengonsep Pariwisata Islami. KARSA: Journal of Social and Islamic Culture, 18(2), 114-122. http://dx.doi.org/10.19105/karsa.v18i2.82

Sembiring, R. (2017). PENGARUH HARGA, KUALITAS, KERAGAMAN PRODUK DAN LOKASI PASAR TERHADAP PREFERENSI KONSUMEN DALAM MEMBELI PRODUK PERTANIAN DI PASAR TRADISIONAL BRASTAGI. JURNAL AGRICA, 9(2), 107. https://doi.org/10.31289/agrica.v9i2.541

Swastha, B. (2001). Manajemen Pemasaran Modern. BPFE.

Tjipto, F. (2008). The Power Of Brans, Teknik Mengelola Brand Equity dan Strategi Pengembangan Merk. PT. Gramedia Pustaka Utama. 